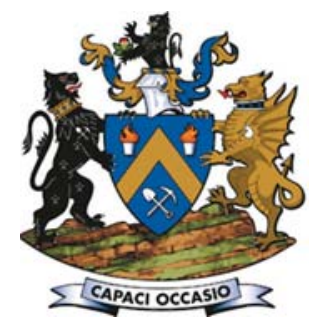

\title{
Chrome ore mineralogy and the furnace mass and energy balance
}

\author{
by N.J. Sweeten* , S.M.C. Verryn ${ }^{\dagger}$, J. Oberholzer ${ }^{\ddagger}$, and \\ J.H. Zietsman*
}

\section{Synopsis}

The effect of ore mineralogy on ferroalloy smelter operation is not sufficiently understood. The ore mineralogy can influence energy and reductant requirements, melting and reaction rates, and effectiveness of prereduction. These are all important factors to consider for furnace design, warranting a deeper study of the effect of ore mineralogy on ferroalloy production processes. This work focuses on smelting furnace mass and energy balances. Furnace mass and energy balances are among the most fundamental calculations done on a regular basis, from the project feasibility stage right through to everyday operations. Whether the energy balance is calculated by a tried and tested spreadsheet calculation, or by applying thermodynamic fundamentals using tools such as FactSage or EMSIM, most engineers simply use a chemical analysis of the raw materials. This ignores the potential effect of the ore's true mineralogical composition and may cause errors, the magnitude of which are not fully understood. In this paper we present the results of mineralogical analyses of South African, Zimbabwean, and Khazakstan chrome ores and compare energy balance results based on standard chemical assays to results based on mineralogical information.

Keywords

chromite smelting, ore mineralogy, mass balance, energy balance.

\section{Background}

Ferroalloy furnace technologies have developed over the years through tried and tested experience. With the technology available today, it is near-sighted to believe that experience will be enough to stay ahead into the future. The companies that control the ferroalloy industry in the future will be those that are able to absorb the most knowledge and draw insights from it to develop better processes.

Most ferrochrome plants take regular ore samples and perform ICP or XRF analyses to determine the chemical composition. These tests measure the contents of various metallic elements, such as $\mathrm{Cr}, \mathrm{Fe}, \mathrm{Si}, \mathrm{Mg}$, and $\mathrm{Ca}$, and report results based on assumed oxidation states. The resulting assays are expressed in terms of $\mathrm{Cr}_{2} \mathrm{O}_{3}, \mathrm{FeO}, \mathrm{SiO}_{2}, \mathrm{MgO}, \mathrm{CaO}$, and various trace elements. In our experience, most producers, and even authors in the literature, use this assay directly in their calculations (Xu, 2013).

The enthalpy of formation of one ton of chromite $\left(\mathrm{FeCr}_{2} \mathrm{O}_{4}\right)$ is $-1458 \mathrm{~kJ} / \mathrm{mol}$, but if the chromite is assumed to be equivalent amounts of $\mathrm{FeO}$ and $\mathrm{Cr}_{2} \mathrm{O}_{3}$, the enthalpy of formation is only $-1393 \mathrm{~kJ} / \mathrm{mol}$ - a difference of $77.4 \mathrm{kWh} / \mathrm{t}$ chromite. These results show that handling ore mineralogy incorrectly has the potential to affect the calculation of the furnace energy requirement. Ex Mente performs numerous furnace mass and energy balance investigations, so it is valuable to us to have insight into the effect of ore mineralogy so that we can make our calculations as accurate as possible. This paper therefore aims to answer the question: To what extent does ore mineralogy influence the furnace mass and energy balance?

\section{Method}

One approach to answer these questions would be direct measurement of the energy required to melt an ore sample, and the reductant required to achieve a specific recovery. Instrumentation for this kind of work is extremely sensitive and it is time-consuming and expensive to obtain accurate results. It was therefore decided to use straightforward ICP-OES and XRD results, and reconcile them as far as possible, and calculate the reductant and energy requirements using Factsage (Bale et al. 2009) equilibrium calculations. Each of these methods is described in this section.

\section{Ore samples}

Several samples were used for this work from different orebodies in South Africa, Zimbabwe, and Khazakstan, as shown in Table I. Grab samples of 2-3 $\mathrm{kg}$ were obtained and were crushed, milled, and split at UIS Analytical

\footnotetext{
Ex Mente, South Africa.

+ XRD Analytical and Consulting, South Africa.

\& UIS Analytical Services, South Africa.

(c) The Southern African Institute of Mining and Metallurgy, 2018. ISSN 2225-6253. This paper was first presented at the INFACON XV: International Ferro-Alloys Congress, 25-28 February 2018, Century City Conference Centre and Hotel, Cape Town, South Africa
} 


\section{Chrome ore mineralogy and the furnace mass and energy balance}

\begin{tabular}{|c|c|c|}
\hline \multicolumn{3}{|c|}{ Ore samples used in this work } \\
\hline Sample name & Country of origin & Mine/description \\
\hline LG6 A & South Africa & LG6 \\
\hline LG6 B & South Africa & LG6 run-of-mine (ROM) \\
\hline MG4 A & South Africa & MG4 \\
\hline MG4 B & South Africa & MG4 lumps \\
\hline ZIM A & Zimbabwe & Ngezi \\
\hline ZIM B & Zimbabwe & Ngezi \\
\hline ZIM C & Zimbabwe & Mapanzuri \\
\hline Marico & South Africa & Marico \\
\hline Khaz & Khazakstan & Unknown \\
\hline
\end{tabular}

Services to ensure homogeneity between the samples used for chemical and mineralogical analysis. Since the samples are grab samples they are not necessarily representative of the orebodies.

\section{Chemical analysis}

All samples were dried, and their moisture content determined to ensure that assay results are reported on a dry basis. For determination of elemental composition, samples were first subjected to sodium peroxide $\left(\mathrm{Na}_{2} \mathrm{O}_{2}\right)$ fusion, followed by dilute hydrochloric acid dissolution. The solutions were then analysed by inductively coupled plasma optical emission spectroscopy (ICP-OES). ICP-OES involves nebulizing a sample of the solution and injecting it into a plasma. The various elements are identified and quantified through their unique optical emission spectra. ICP-OES was used for the analysis of both major and minor elements.

In addition to the elemental analysis, the oxidation states of iron $\left(\mathrm{Fe}^{2}+/ \mathrm{Fe}^{3+}\right.$ ratio) were determined by selective dissolution of $\mathrm{Fe}^{3}+$ with hydrochloric acid, while assuming that $\mathrm{Fe}^{2+}$ in the chromite will not dissolve. The solution was then analysed by ICP-OES to determine the $\mathrm{Fe}^{3+}$ concentration. This procedure is proposed here as a new method for determining the $\mathrm{Fe}^{2+} / \mathrm{Fe}^{3+}$ ratio of chromite ores. This property is typically difficult or impossible to measure by other methods.

In the LECO analysis, carbon and sulphur contents were determined by using a high-frequency combustion instrument with infrared detection. Hydrogen and nitrogen contents were determined using a $\mathrm{H} / \mathrm{N}$ elemental analyser.

To complete the chemical analysis, the loss on ignition (LOI) was determined. This was done by determining the mass change of a sample while heating it to a temperature of $1000^{\circ} \mathrm{C}$ for 2 hours, in air. The heating process releases crystal water, water from hydroxide compounds, $\mathrm{CO}_{2}$ from carbonates, and $\mathrm{SO}_{2}$ from sulphates. The analysis therefore aims to determine the content of such volatile matter in the sample. LOI tests in an oxidizing atmosphere can return a negative result, indicating a gain on ignition. This can be the result of, for example, $\mathrm{FeCr}_{2} \mathrm{O}_{4}$ being oxidized to $\mathrm{Fe}_{2} \mathrm{O}_{3}+$ $\mathrm{Cr}_{2} \mathrm{O}_{4}$.

\section{Mineralogical analysis}

The ore mineralogical composition was determined by X-ray powder diffraction (XRD) (Loubser and Verryn, 2008). XRD identifies and quantifies the phases in a sample from their unique powder diffraction patterns. This technique uses the crystalline structure of the different minerals and is therefore able to distinguish between spinels such as $\mathrm{FeCr}_{2} \mathrm{O}_{4}$ and $\mathrm{MgAl}_{2} \mathrm{O}_{4}$ and other oxide phases.

\section{Reconciliation}

The goal of the reconciliation was to convert the chemical and mineralogical assays to calculated mineralogical assays that reflect the same chemical composition as the chemical analysis results, while remaining as close as possible to the measured mineralogical composition. This was done by manually assigning elements to known minerals and equilibrating the remainder of the assay to calculate an approximated chemical composition of multi-component minerals such as spinels.

\section{Thermodynamic equilibrium}

Calculating thermochemical equilibrium is an important part of the reconciliation procedure. FactSage (Bale et al., 2009) contains data based on thousands of experiments and uses rigorous optimization routines to determine the equilibrium state of elements in hundreds of phase structures. The equilibrium state is the state of the lowest Gibbs free energy and therefore the most likely condition that will be reached, given enough time.

Ores are unlikely to be at thermodynamic equilibrium due to the numerous processes that led to their formation and the weathering that changed their structures over the years. It is therefore necessary to manipulate the equilibrium calculations to achieve a representative assay.

FactSage takes account of solid solutions such as spinels and pyroxenes that consist of various constituents. The calculations incorporate the heats of mixing of these various phases, which is more accurate than assuming that $\mathrm{FeCr}_{2} \mathrm{O}_{3}$ and $\mathrm{MgCr}_{2} \mathrm{O}_{3}$ are two separate spinels, when in fact they are together in solution.

\section{Mass and energy balance}

A simplified mass and energy balance was calculated for each of the ores. Several assumptions were made to simplify the calculations:

1. Pure graphite $(\mathrm{C})$ was used as the reductant to remove the effect of ash and volatile matter from actual reductants.

2. No flux was added to any of the calculations. Fluxing design is critical to ensure effective furnace operation, but flux adds complications that might obscure the ore effects that are the focus here.

3. The reagents (ore and graphite) were equilibrated at $1700^{\circ} \mathrm{C}$. This temperature was used throughout this study to allow for comparison on the same basis.

4. A chrome recovery to alloy of $95 \%$ was selected for the furnace and the graphite was adjusted to achieve this recovery for each case.

\section{Results and discussion}

\section{Chemical analysis}

Table II shows the chemical analysis results for the ore samples. The LG6 A ore has the highest content of $\mathrm{Cr}_{2} \mathrm{O}_{3}$, the lowest $\mathrm{SiO}_{2}$, and the highest $\mathrm{Cr} / \mathrm{Fe}$ ratio of the South African ores. The Zimbabwean ores have much higher $\mathrm{Cr} / \mathrm{Fe}$ ratios. 
Table II

Chemical analysis results (in mass \%) for the ferrochrome ores under consideration

\begin{tabular}{|c|c|c|c|c|c|c|c|c|c|}
\hline & LG6 A & LG6 B & MG4 A & MG4 B & ZIM A & ZIM B & ZIM C & Marico & Khaz \\
\hline \multicolumn{10}{|l|}{ Main } \\
\hline $\mathrm{Cr}_{2} \mathrm{O}_{3}$ & 43.13 & 39.77 & 30.99 & 29.97 & 39.62 & 42.54 & 34.8 & 49.708 & 49.1232 \\
\hline $\mathrm{Fe}_{2} \mathrm{O}_{3}$ & 0.81 & 0.96 & 0.44 & 0.72 & 5.44 & 2.5 & 2.29 & 0.71 & 0.62 \\
\hline $\mathrm{FeO}$ & 23.29 & 21.92 & 21.77 & 21.64 & 13.02 & 14.51 & 13.16 & 20.25 & 11.24 \\
\hline $\mathrm{Cr} / \mathrm{Fe}$ & 1.6 & 1.5 & 1.2 & 1.2 & 1.9 & 2.2 & 2 & 2.1 & 3.7 \\
\hline \multicolumn{10}{|c|}{ Major gangue } \\
\hline $\mathrm{SiO}_{2}$ & 3.47 & 7.97 & 15.4 & 15.84 & 9.52 & 10.41 & 14.42 & 4.03 & 6.22 \\
\hline $\mathrm{Al}_{2} \mathrm{O}_{3}$ & 15.53 & 14.14 & 14.7 & 14.88 & 12.2 & 11.6 & 11.1 & 12.5 & 8.07 \\
\hline $\mathrm{CaO}$ & 0.47 & 0.71 & 3.13 & 3.97 & 0.23 & 0.22 & 0.27 & 0.2 & 0.2 \\
\hline $\mathrm{MgO}$ & 10 & 11.68 & 10.06 & 9.74 & 16.38 & 15.12 & 21 & 10.4 & 21.1 \\
\hline \multicolumn{10}{|c|}{ Minor gangue } \\
\hline $\mathrm{TiO}_{2}$ & 0.63 & 0.59 & 0.83 & 0.98 & 0.34 & 0.39 & 0.32 & 0.45 & 0.15 \\
\hline $\mathrm{MnO}$ & 0.29 & 0.29 & 0.23 & 0.24 & 0.26 & 0.24 & 0.16 & 0.2 & 0.13 \\
\hline $\mathrm{V}_{2} \mathrm{O}_{5}$ & 0.34 & 0.3 & 0.32 & 0.34 & 0.19 & 0.2 & 0.17 & 0.63 & 0.2 \\
\hline \multicolumn{10}{|l|}{ Trace } \\
\hline $\mathrm{K}_{2} \mathrm{O}$ & 0.03 & 0.033 & 0.034 & 0.044 & 0.019 & 0.024 & 0.023 & 0.008 & 0.035 \\
\hline $\mathrm{Zn}$ & 0.093 & 0.084 & 0.078 & 0.081 & 0.089 & 0.073 & 0.06 & 0.1 & 0.065 \\
\hline $\mathrm{Ba}$ & 0.003 & 0.003 & 0.005 & 0.003 & 0.003 & 0.002 & 0.001 & 0.001 & 0.001 \\
\hline $\mathrm{Cu}$ & 0.002 & 0.002 & 0.003 & 0.003 & 0.001 & 0.002 & 0.002 & 0.001 & 0.002 \\
\hline $\mathrm{Ni}$ & 0.083 & 0.081 & 0.086 & 0.084 & 0.127 & 0.123 & 0.142 & 0.062 & 0.13 \\
\hline \multicolumn{10}{|l|}{ Other } \\
\hline $\mathrm{CO}_{2}$ & 0.121 & 0.337 & 0.059 & 0.029 & 0.311 & 0.289 & 0.326 & 0.106 & 0.242 \\
\hline $\mathrm{H}_{2} \mathrm{O}$ & $<0.005$ & $<0.005$ & $<0.005$ & $<0.005$ & 1.591 & 0.304 & 0.769 & 0.954 & 2.178 \\
\hline $\mathrm{N}$ & 0 & 0 & 0 & 0 & 0.059 & 0.03 & 0.01 & $<0.01$ & $<0.01$ \\
\hline S & 0.003 & 0.007 & 0.008 & 0.003 & 0.004 & 0.01 & 0.007 & $<0.003$ & 0.024 \\
\hline Moisture & 0 & 0 & 0 & 0 & 0.48 & 0.34 & 0.08 & 0.06 & 0.06 \\
\hline LOI & -0.42 & -0.16 & -0.74 & -0.44 & 2.81 & 2.15 & 2.79 & -0.98 & 1.98 \\
\hline
\end{tabular}

Table III

XRD analysis results (in mass \%) for South African LG6 samples, with and without plagioclase

\begin{tabular}{|c|c|c|c|c|c|}
\hline Mineral & Chemical formula & LG6 A & LG6 A new & LG6 B & LG6 B new \\
\hline Chromite & $\mathrm{FeCr}_{2} \mathrm{O}_{4}$ & 23.06 & 25.65 & 16.81 & 19.21 \\
\hline Chromite1 & $\mathrm{FeCr}_{2} \mathrm{O}_{4}$ & 14.38 & 16.32 & 22.28 & 23.39 \\
\hline Magnesiochromite & $\mathrm{MgCr}_{2} \mathrm{O}_{4}$ & 40.89 & 40.72 & 32.56 & 31.35 \\
\hline Chlorite & $\mathrm{Mg}_{5} \mathrm{Al}_{2} \mathrm{Si}_{3} \mathrm{O}_{10}(\mathrm{OH})_{8}$ & 1.45 & 1.64 & 3.37 & 2.19 \\
\hline Plagioclase & $\mathrm{NaAISi}_{3} \mathrm{O}_{8}, \mathrm{CaAl}_{2} \mathrm{Si}_{2} \mathrm{O}_{8}$ & 13.02 & & 14.75 & \\
\hline Enstatite & $\mathrm{MgSiO}_{3}$ & & 8.51 & & 16.35 \\
\hline Vermiculite & & 6.46 & 6.75 & 7.71 & 7.22 \\
\hline Dolomite & $\mathrm{CaMg}\left(\mathrm{CO}_{3}\right)_{2}$ & 0.74 & 0.40 & 2.52 & 0.30 \\
\hline
\end{tabular}

They also tend to have less $\mathrm{Al}_{2} \mathrm{O}_{3}$ and higher $\mathrm{MgO}$ than South African ores. The South African ores exhibited a gain on ignition; this is likely due to iron being oxidized during the test. The assays all summed to less than $100 \%$, which is typical for chemical analysis results. The Zimbabwean ores were slightly wet, whereas the South African ores contained no moisture. All calculations in this work were done on a dry-ore basis to standardize the calculations.

The $\mathrm{H}$ and $\mathrm{C}$ results from the $\mathrm{LECO}$ analyses were converted to $\mathrm{H}_{2} \mathrm{O}$ and $\mathrm{CO}_{2}$ respectively. No $\mathrm{H}$ was detected in the South African samples, but the LECO is designed for analysing coals, so it is not optimized for detecting small amounts of $\mathrm{H}$.

\section{Mineralogical analysis}

Table III shows two sets of XRD results for the LG6 A and LG6 B samples, and Table IV shows the results for the remaining ores. Three different spinel phases were detected by XRD; they are named chromite, chromite1, and magnesiochromite by the XRD software. 


\section{Chrome ore mineralogy and the furnace mass and energy balance}

\begin{tabular}{|c|c|c|c|c|c|c|c|c|}
\hline Mineral & Chemical formula & MG4 A & MG4 B & ZIM A & ZIM B & ZIM C & Marico & Khaz \\
\hline Chromite & $\mathrm{FeCr}_{2} \mathrm{O}_{4}$ & 40.39 & 51.83 & 42.51 & 61.36 & 64.29 & 97.51 & 87.21 \\
\hline Chromite1 & $\mathrm{FeCr}_{2} \mathrm{O}_{4}$ & & & 33.50 & 17.45 & & & \\
\hline Lizardite & $\mathrm{Mg}_{3} \mathrm{Si}_{2} \mathrm{O}_{5}(\mathrm{OH})_{4}$ & & & 9.79 & 10.36 & 11.46 & & 12.79 \\
\hline Chlorite & $\mathrm{Mg}_{5} \mathrm{Al}_{2} \mathrm{Si}_{3} \mathrm{O}_{10}(\mathrm{OH})_{8}$ & & & 5.14 & 3.30 & 4.19 & & \\
\hline Haematite & $\mathrm{Fe}_{2} \mathrm{O}_{3}$ & & & 5.60 & 2.19 & 0.83 & & \\
\hline Goethite & $\mathrm{FeO}(\mathrm{OH})$ & & & 3.47 & 5.35 & 0.06 & & \\
\hline Enstatite & $\mathrm{MgSiO}_{3}$ & 19.37 & 11.59 & & & 13.12 & & \\
\hline Diopside & $\mathrm{MgCaSi}_{2} \mathrm{O}_{6}$ & 1.60 & 7.93 & & & 6.05 & 2.49 & \\
\hline Plagioclase & $\mathrm{NaAlSi}_{3} \mathrm{O}_{8}, \mathrm{CaAl}_{2} \mathrm{Si}_{2} \mathrm{O}_{8}$ & 31.63 & 21.37 & & & & & \\
\hline Kaolinite & $\mathrm{Al}_{2} \mathrm{Si}_{2} \mathrm{O}_{5}(\mathrm{OH})_{4}$ & 0.00 & 0.34 & & & & & \\
\hline Talc & $\mathrm{Mg}_{3} \mathrm{Si}_{4} \mathrm{O}_{10}(\mathrm{OH})_{2}$ & 1.37 & 1.36 & & & & & \\
\hline Smectite & & 1.82 & 2.71 & & & & & \\
\hline Actinolite & $\mathrm{Ca}_{2} \mathrm{Fe}_{5} \mathrm{Si}_{8} \mathrm{O}_{22}(\mathrm{OH})_{2}$ & 3.82 & 2.87 & & & & & \\
\hline
\end{tabular}

The LG6 chemical analysis results showed very little CaO in the ore, and no Na. Therefore, it unlikely that the ore contains as much plagioclase as suggested by the preliminary XRD results in Table III. Plagioclase and enstatite peaks can, however, overlap in the diffractogram. The XRD results were therefore updated to favour enstatite, which is much more likely given the chemical composition of the sample. This illustrates the importance of critically analysing any laboratory results, and of providing the mineralogist with a chemical assay to assist in interpreting XRD results. Chromites of different compositions were detected and the simplified chemical formulae shown in the table do not necessarily reflect the actual composition.

The XRD results show that the LG6 ores contain chlorite and vermiculite. These are both hydrated minerals, but the chemical composition results show that the hydrogen contents of the ores are below the $0.05 \%$ detection limit of the LECO. For this reason, the ores were assumed to contain $0.05 \%$ water.

\section{Mineralogical reconciliation}

The mineralogical reconciliation was performed to convert the chemical analysis into a calculated mineralogical assay as close as possible to the measured mineralogical composition. The mass and energy balance was then compared using the measured chemical assay and the calculated mineralogical assay. In the reconciliation, the chemical assays were used as the primary source of information, since chemical analyses are fully quantitative and more accurate than XRD analysis. The chemical analysis results were therefore used as the basis, with the XRD results as a guide.

\section{South African LG and MG ores}

The following steps were used to produce a calculated mineralogical assay from the measured chemical and mineralogical assays.

1. The trace elements were removed from the chemical assay to simplify the thermochemical equilibrium calculations. The assay was normalized by proportionally increasing the gangue elements in their oxide forms $\left(\mathrm{SiO}_{2}, \mathrm{CaO}, \mathrm{MgO}\right.$, and $\left.\mathrm{Al}_{2} \mathrm{O}_{3}\right)$ so that the final assay summed to $100 \%$. This allows for trace elements to be substituted by gangue minerals, rather than normalizing the entire assay, which would increase the amounts of iron and chromium above their measured values, causing an over-estimation of chrome production.

2. The carbon from the LECO analyses was used to form dolomite, and the required amounts of $\mathrm{CaO}$ and $\mathrm{MgO}$ were removed from the chemical assay. The amount of dolomite calculated for the MG ores is below the typical XRD detection limit, which is why it was not identified by XRD. Dolomite is the most likely carboncontaining phase, therefore it was assumed that all the carbon is present in dolomite.

3. The remaining $\mathrm{CaO}$ was used to form plagioclase.

4. It was assumed that the ores contain $0.05 \%$ water. The LECO test is unable to detect water below this limit. This assumption was made because the XRD results suggest that there are hydrated minerals in the ores. This water was used to make chlorite.

5. The remainder of the assay was equilibrated at $25^{\circ} \mathrm{C}$ to approximate the spinel and orthopyroxene phases. The equilibrium phases allowed in the calculation were restricted to produce the desired result:

(i) LG6 A and B

(a) Only $\mathrm{MgO}, \mathrm{FeO}, \mathrm{Al}_{2} \mathrm{O}_{3}$, and $\mathrm{Cr}_{2} \mathrm{O}_{3}$ were provided as inputs to the calculation.

(b) Three spinel phases were allowed to form because three distinct spinel phases were observed by XRD.

(c) $\mathrm{MgO}, \mathrm{FeO}, \mathrm{Al}_{2} \mathrm{O}_{3}$, and $\mathrm{Cr}_{2} \mathrm{O}_{3}$ were allowed to form as individual compounds.

(d) A stable gas phase was forced by adding Ar. This was done to improve numerical stability and speed of convergence.

(ii) MG4 and MG4

(a) Only $\mathrm{SiO}_{2}, \mathrm{MgO}, \mathrm{FeO}, \mathrm{Al}_{2} \mathrm{O}_{3}$, and $\mathrm{Cr}_{2} \mathrm{O}_{3}$ were provided as inputs to the calculation.

(b) One spinel phase was allowed to form because only one spinel phase was detected by XRD. 


\section{Chrome ore mineralogy and the furnace mass and energy balance}

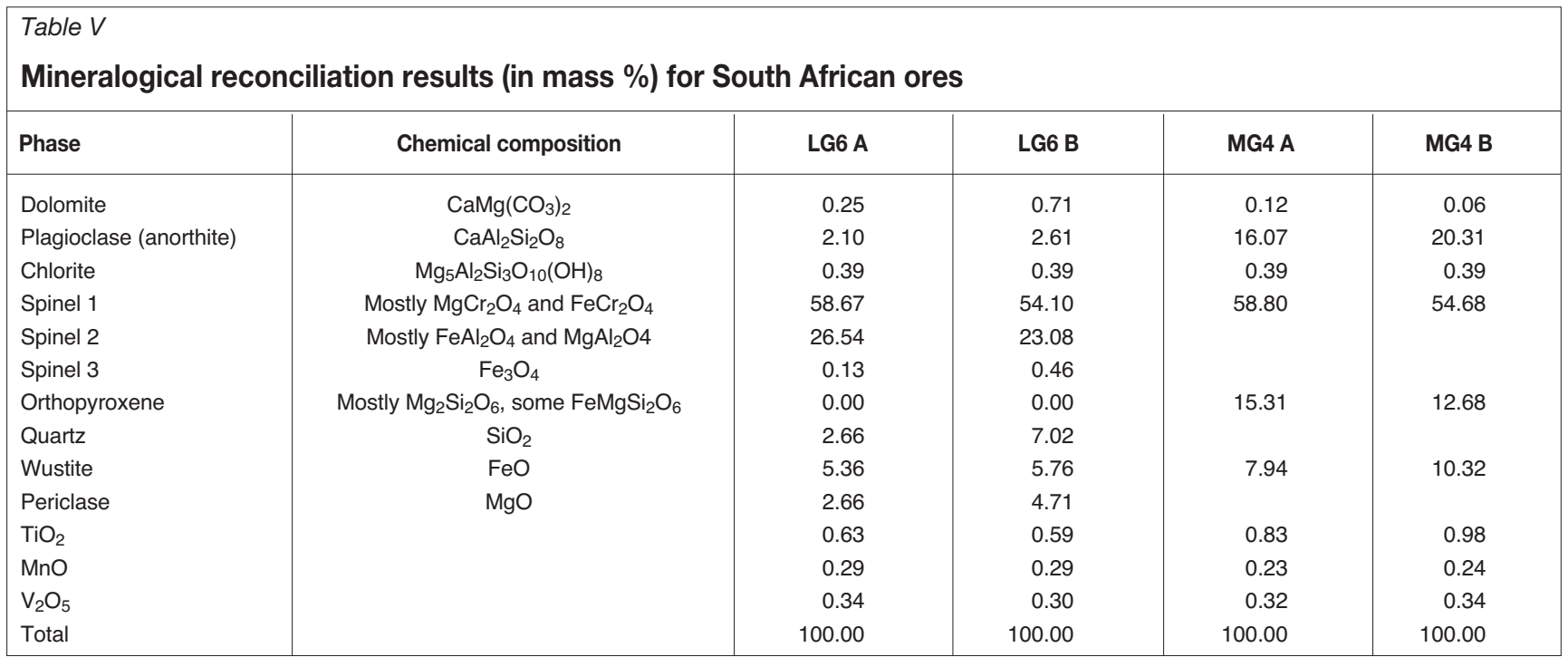

(c) $\mathrm{MgO}, \mathrm{FeO}, \mathrm{Al}_{2} \mathrm{O}_{3}$, and $\mathrm{Cr}_{2} \mathrm{O}_{3}$ were allowed to form as individual compounds.

(d) Orthopyroxene, talc, and clinopyroxene were allowed to form. There was no remaining $\mathrm{CaO}$ to form clinopyroxene, or water to form talc.

(e) A stable gas phase was again forced with Ar.

The results are shown in Table V.

\section{Zimbabwean ores}

The reconciliation for the Zimbabwean ores was similar, but with some changes to reflect the different mineralogical and chemical assay results:

1. The gangue portion of the assay was normalized to account for the mass of the trace elements

2. The LECO results suggest that there is a small amount of carbon in the ore. The most likely source of this is dolomite. No dolomite was detected by XRD, but it is likely that it is below the detection limit. The carbon was therefore allocated to the dolomite phase.

3. For ZIM A and ZIM B, the XRD results suggest that there is more $\mathrm{Fe}^{3+}$ (in haematite and goethite), than the chemical results allow for. All the $\mathrm{Fe}^{3+}$ was set aside for these phases, and divided between goethite and haematite in the ratios suggested by the XRD results. For the ZIM C ore, the haematite and goethite are less than the amount of $\mathrm{Fe}^{3+}$. The $\mathrm{Fe}^{3+}$ required to make up the amounts of goethite and haematite from the XRD results was set aside and the remainder of the $\mathrm{Fe}^{3+}$ was allocated to the spinel phase.

4. Some of the water was already allocated to the goethite phase, as indicated above. The remaining water, from the chemical results, was allocated to the lizardite and chlorite phases in the ratio between the phases suggested by the XRD results.

5. The spinels were generated by equilibrating the remaining elements in oxide form at $25^{\circ} \mathrm{C}$.

The results for the Zimbabwean ores are shown in Table VI.

\section{Other ores}

The Marico and Khazakstan ores are similar in that they both have an extremely high content of a single spinel phase. These samples were received at a later stage in the investigation, so there was insufficient time to perform as meticulous a reconciliation as was done for the other ores. Nevertheless, the results are included here for interest's sake. Similar steps were taken to reconcile the mineralogies of these ores.

1. The gangue portion of the assay was normalized to account for the mass of the trace elements.

2. The chemical assay was then equilibrated with restricted phases:

a. One spinel phase was allowed.

b. Each of the simple oxides for the available elements was allowed to form to ensure that the mass balance could be calculated.

c. For the Marico ore, clinopyroxene (diopside) was allowed, and for the Khazakstan ore lizardite was allowed.

3. The elements that did not fit into the spinel or accompanying phases were left as pure substances, as shown in Table VII.

The results for the Marico and Khazakstan ores are shown in Table VII.

\section{Mass and energy balance}

Table VIII show the mass and energy balance results for three cases for each of the ores

1. Assay as given by chemical analysis, with all $\mathrm{Fe}$ as $\mathrm{FeO}$.

2. Assay as given by chemical analysis, with forms of iron as determined by analytical work.

3. Mineralogical assay calculated through reconciliation.

\section{Mass balance}

The differences in the mass balance depend solely on the oxidation state of the iron in the ore. A new method is proposed to measure the $\mathrm{Fe}^{2+} / \mathrm{Fe}^{3}+$ ratio of chrome ore, but 


\section{Chrome ore mineralogy and the furnace mass and energy balance}

\begin{tabular}{|c|c|c|c|c|}
\hline Phase & Chemical composition & ZIM A & ZIM B & ZIM C \\
\hline Dolomite & $\mathrm{CaMg}\left(\mathrm{CO}_{3}\right)_{2}$ & 0.65 & 0.61 & 0.68 \\
\hline Haematite & $\mathrm{Fe}_{2} \mathrm{O}_{3}$ & 3.49 & 0.78 & 0.83 \\
\hline Goethite & $\mathrm{Fe}_{2} \mathrm{O}_{3}\left(\mathrm{H}_{2} \mathrm{O}\right)$ & 2.17 & 1.91 & 0.06 \\
\hline Lizardite & $\mathrm{Mg}_{3} \mathrm{Si}_{2} \mathrm{O}_{5}(\mathrm{OH})_{4}$ & 6.92 & 0.64 & 4.30 \\
\hline Chlorite & $\mathrm{Mg}_{5} \mathrm{Al}_{2} \mathrm{Si}_{3} \mathrm{O}_{10}(\mathrm{OH})_{8}$ & 3.63 & 0.20 & 1.57 \\
\hline Spinel 1 & $\mathrm{MgCr}_{2} \mathrm{O}_{4}, \mathrm{FeCr}_{2} \mathrm{O}_{4}$ & 52.95 & 57.15 & 47.57 \\
\hline Spinel 2 & $\mathrm{FeAl}_{2} \mathrm{O}_{4}, \mathrm{MgFe}_{2} \mathrm{O}_{4}$ & 19.39 & 19.90 & 19.43 \\
\hline Orthopyroxene & Mostly $\mathrm{Mg}_{2} \mathrm{Si}_{2} \mathrm{O}_{6}$, some $\mathrm{FeMgSi}_{2} \mathrm{O}_{6}$ & & & \\
\hline Lime & $\mathrm{CaO}$ & 0.03 & 0.04 & 0.07 \\
\hline Quartz & $\mathrm{SiO}_{2}$ & 5.57 & 10.53 & 12.42 \\
\hline Periclase & $\mathrm{MgO}$ & 4.41 & 7.39 & 12.30 \\
\hline Wüstite & $\mathrm{FeO}$ & & & 0.11 \\
\hline $\mathrm{TiO}_{2}$ & & 0.34 & 0.39 & 0.32 \\
\hline $\mathrm{MnO}$ & & 0.26 & 0.24 & 0.16 \\
\hline $\mathrm{V}_{2} \mathrm{O}_{5}$ & & 0.19 & 0.20 & 0.17 \\
\hline Total & & 100.00 & 100.00 & 100.00 \\
\hline
\end{tabular}

\begin{tabular}{|c|c|c|c|}
\hline \multicolumn{4}{|l|}{ Table VII } \\
\hline \multicolumn{4}{|c|}{$\begin{array}{l}\text { Mineralogical reconciliation results (in mass \%) for } \\
\text { other ores }\end{array}$} \\
\hline Phase & Chemical composition & Marico & Khaz \\
\hline Haematite & $\mathrm{Fe}_{2} \mathrm{O}_{3}$ & 0.55 & \\
\hline Lizardite & $\mathrm{Mg}_{3} \mathrm{Si}_{2} \mathrm{O}_{5}(\mathrm{OH})_{4}$ & & 14.56 \\
\hline Spinel 1 & $\mathrm{MgCr}_{2} \mathrm{O}_{4}, \mathrm{FeCr}_{2} \mathrm{O}_{4}$ & 90.15 & 82.96 \\
\hline Orthopyroxene & Mostly $\mathrm{Mg}_{2} \mathrm{Si}_{2} \mathrm{O}_{6}$, some $\mathrm{FeMgSi}_{2} \mathrm{O}_{6}$ & 7.09 & \\
\hline Lime & $\mathrm{CaO}$ & & 0.2 \\
\hline Periclase & $\mathrm{MgO}$ & & 1.7 \\
\hline $\mathrm{TiO}_{2}$ & & 0.45 & 0.15 \\
\hline $\mathrm{MnO}$ & & 0.20 & 0.13 \\
\hline $\mathrm{V}_{2} \mathrm{O}_{5}$ & & 0.63 & 0.2 \\
\hline
\end{tabular}

this method requires validation against standard samples to ensure its effectiveness.

The $\mathrm{Fe}^{2+/} \mathrm{Fe} 3+$ ratio directly affects the mass balance because if the iron is more oxidized, more reductant is required to reduce it. There are two reasons to believe that the methods of iron analysis may be underestimating the Fe3+ content:

1. The XRD results, particularly for the Zimbabwean ores, suggest much higher haematite and goethite than the measured $\mathrm{Fe}^{3}+$ content accounts for.

2. All the equilibrium calculations had 'left-over' FeO that did not 'fit' in the spinel phases. This is obviously an unrealistic result, and is another possible indication that more of the iron might be present as $\mathrm{Fe}^{3+}$.

Preliminary calculations using the Zimbabwean ores, which were based more strongly on the XRD results, suggested a much higher $\mathrm{Fe}^{3}+$ content because of the haematite and goethite measured by XRD. This resulted in carbon requirements as much as $15 \%$ higher than calculated when assuming all iron is present as FeO. This result correlates with industrial experience of higher reductant requirements for Zimbabwean furnaces than South African ones. The reductant requirement results are therefore inconclusive until the ore $\mathrm{Fe}^{2+/} \mathrm{Fe} 3+$ ratio can be confirmed.

\section{Energy balance}

The difference in iron oxidation states does not have as significant an impact on the energy balance as the difference indicated by the approximated mineralogical assay. This shows that using phases such as spinels to represent the ore has a more significant effect on the energy balance than knowing the $\mathrm{Fe}^{2+/ \mathrm{Fe}^{3}+\text { ratio. }}$

The difference in the energy balance when using a chemical assay and the approximated mineralogical assays developed in this work is in the order of $5 \%$. This means that, provided the calculated mineralogical assay is a more accurate representation of the ore, then using a chemical assay for energy balance calculations results in the smelting energy requirement being underestimated by approximately $5 \%$. In practice, this $5 \%$ is being consumed in the furnace, but it is most likely accounted as heat losses rather than due to the theoretical smelting energy requirement of the ore.

\section{Differences between ores}

Any discussion on the differences between the ores analysed in this paper is limited, because the samples used are not necessarily representative of the various orebodies. In addition, different fluxes would be required for the different ores and these have not been considered. It is, however, interesting to draw some preliminary conclusions.

The South African ores tend to have lower smelting energy requirements than the Zimbabwean ores. LG6 A ore has the lowest energy requirement and highest yield of alloy per ton of ore. ZIM B has the lowest energy requirement and highest yield of alloy per ton ore of the Zimbabwean ores.

\section{Conclusions and recommendations}

\section{Mass balance}

The amount of reductant required has been shown to be 


\section{Chrome ore mineralogy and the furnace mass and energy balance}

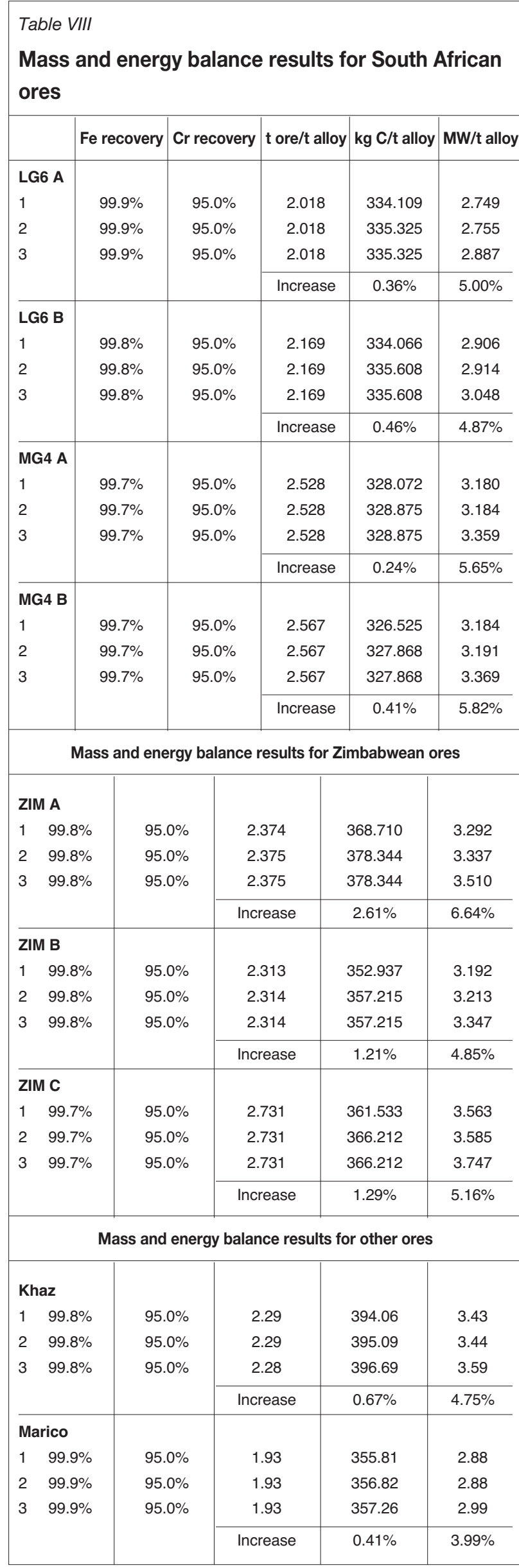

strongly dependent on the $\mathrm{Fe}^{2+} / \mathrm{Fe}^{3+}$ ratio. A new method was proposed and used to determine the oxidation states of iron. The XRD results and reconciliation suggest that the Fe3+ contents may be higher than measured by this new method. It is recommended that the method be validated using standard samples of known iron oxidation state to improve its accuracy, and that it be routinely used when analysing ore samples for mass and energy balances.

\section{Energy balance}

The energy balance results suggest that the calculated energy requirement is approximately $5 \%$ higher when using the approximated mineralogical assays compared to chemical assays. These results are by no means conclusive, because they are also based upon several assumptions, but they have shown that using a mineralogical composition makes a difference in the energy balance. These results should be verified using analytical techniques for measuring the actual energy requirement directly.

With today's strong focus on maximizing energy efficiency, it is critical to obtain as good an understanding of the furnace energy balance as possible. Understanding ore mineralogy is an important part of this. One option for improving this understanding is to smelt ore samples under controlled conditions, measure the actual energy requirement, and compare that to these approximated results. Another is to measure the heat of formation of the ore directly. The feasibility of both these options is speculative at this stage.

These results may not be so critical to operating plants that have long since made accommodations for their energy balances, but they are worthwhile for designers of future furnaces to understand. The analyses performed in this work are not expensive, and the method proposed here can be used to reconcile the analyses and produce more accurate assays for mass and energy balances.

Finally, to answer the initial question: ore mineralogy does influence both mass and energy balance calculations for ferrochrome smelting furnaces. The extent of this influence depends on the specific ore, but it has been shown that both reductant and energy requirement calculations are impacted. Reductant requirement differences are small enough to be within the band of uncertainty due to variations in raw material composition, and sampling and analytical error. Smelting energy requirement differences appear to be more significant, and these could prove to be important when switching between different raw materials, or when doing feasibility and design calculations for new plants.

\section{References}

Bale, C.W., Bélisle, E., Chartrand, P., Decterov, S. A., Eriksson, G., Gheribi, A. Hack, K., Jung, I-H., Melançon, J., Pelton, A.D., Petersen, S., and Robelin, C. 2009. FactSage thermochemical software and databases - recent developments. Calphad, vol. 33. pp. 295-311.

LOUBSER, M. and VERRYN, S. 2008. Combining XRF and XRD analyses and sample preparation to solve mineralogical problems. Journal of the Geological Society of South Africa, vol. 111. pp. 229-238.

PAN, X. 2013. Effect of South Africa chrome ores on ferrochrome production. Proceedings of the International Conference on Mining, Mineral Processing and Metallurgical Engineering (ICMMME'2013), Johannesburg, South Africa, 15-16 April 2013. pp. 106-110. 